\title{
㐘周病のリスフファフターとしての外傷性咬合 Traumatic Occlusion as a Risk Factor for Periodontal Disease
}

姫路市 勝谷歯科医院 勝谷芳文

歯周病と咬合との関わりについて歴史的に見てみると、古く 1950 以前には、歯周病 の主な原因が外傷性咬合にあると考えられていた。その後 Orban，G1ickman， Waerhaug らの研究により、咬合性外傷の病変は可逆的な変化であり、外傷性咬合の みによって歯肉の炎症や歯周ポケットの形成などは生じないことが示された。現在 では、歯周病はデンタルプラーク中の菌周病関連細菌によって引き起こされる炎症性 疾患であり、歯周病の病因論的視点からは、咬合はあまり関係のない要因と考えられ ている。一方、すでに発症した歯周炎の局所に外傷力が働いた場合の影響について は、咬合性外傷は歯周病の進展増悪にあまり関係しないとする考え方と、骨吸収と付 着の㳖失をより促進するとする考え方があり、見解の統一をみていない。しかしな がら、Glickman の共同破壊説に代表される後者の意見が、現在の主流の考え方と思わ れる。すなわち、歯周治療という観点からは、咬合性外傷のコントロールが大変重 要な問題となる場合が多いと考えられる。したがって、歯周治療を行ううえで、炎 症の診查・診断とともに、咬合の診査・診断が大切な治療ステップとなる。咬合の 診查・診断のポイントは、(1)セントリックストップの安定性、(2)アンテリアーガイダ ンスの安定性、(3)ブラキシズムの有無、これら3つのポイントを見逃さないように、 すべての症例について、常にチェックをすることが大切である。その結果、咬合治 療の必要性という観点から歯周病の患者を 3 つタイプに分けることが出来る。

I ）咬合の不調和、悪習廦を認めないケース、II）咬合の問題を有しているが見在は 咬合性外傷を認めないケース、III）すでに咬合性外傷を生じているケース。

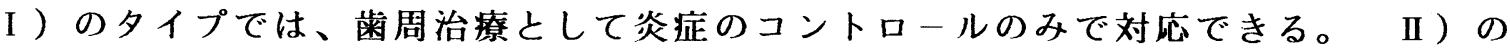
タイプではさしあたって予防的咬合治療の必要はないが、将来問題となる可能性のあ る咬合上のリスクを有しているため、メインテナンス時の綿密な咬合之咬合性外傷の チェックが必要である。 III ) のタイプでは、効果的な歯周治療を行うために炎症の コントロールと咬合性外傷のコントロ-ルが不可欠となる。

臨床の現場では、咬合性外傷のコントロールは歯科医師が行い、歯科衛生士は、主 に、T B I 、スケーリング、ルートプレーニングなどの炎症のコントロールを担当す ることになるが、歯科衛生士も歯周病と外傷性咬合との関わりについてある程度の知 識を持っておいてほしいと思う。そして、咬合性外傷の徵候をいち早くキャッチで きれば理想的である。今回の講演では、茵周病と咬合との関わりについて症例を交 えながらできるだけ解り易く解説する予定である。 